\title{
CORRESPONDENCE AND NOTES
}

\section{Isotopic $\mathrm{U}-\mathrm{Pb}$ ages of zircon and monazite from the Leinster Granite, southeast Ireland}

\section{P. J. O'CONNOR*, M. AFTALION† \& P. S. KENNAN}

* Geological Survey of Ireland, Beggars Bush, Haddington Road, Dublin 4, Ireland

$\dagger$ Scottish Universities Research \& Reactor Centre, East Kilbride, Glasgow G75 0QU, U.K.

$\ddagger$ Department of Geology, University College Belfield, Dublin 4, Ireland

\section{(Received 20 October 1988; accepted 8 May 1989)}

\begin{abstract}
A more precise age for the synkinematic emplacement of the large S-type Leinster batholith (southeast Ireland) has been obtained by $\mathrm{U}-\mathrm{Pb}$ dating of zircon and monazite separates from the two main granite varieties of the Northern Pluton. A concordant age of $405 \pm 2 \mathrm{Ma}$ derived from monazite is considered to reflect both the age of intrusion and the main regional deformation event (DI) in southeast Ireland. The monazite age is in good agreement with an earlier, less precise whole-rock $\mathrm{Rb}-\mathrm{Sr}$ isochron determination. The zircon data indicate recent $\mathrm{Pb}$ loss effects and the existence of a small component of inherited radiogenic $\mathrm{Pb}$ derived from a crustal precursor during the generation of the batholith.
\end{abstract}

\section{The Leinster Granite}

The late Caledonian Leinster Granite batholith dominates the paratectonic Caledonides of southeast Ireland. The batholith comprises five contiguous, concordant and simultaneously emplaced plutons ('Units' of Brindley, 1973), separated from each other by narrow screens of schist and strongly foliated granite. The plutons, arranged en échelon, are emplaced into a thick Lower Palaeozoic sequence of slates, greywackes and quartzites which includes important developments of Ordovician calc-alkaline volcanic rocks. The youngest exposed Lower Palaeozoic formations, deformed prior to granite emplacement, are Lower Wenlock in age (Colthurst \& Smith, 1977).

The Northern Pluton is zoned (Fig. 1) and five granite varieties have been recognized (Brück, 1974): Type 1 granite, Porphyritic Microcline Type II granite, Equigranular Type II granite, Type III granite and Type IV granite. Type I is a fine-grained quartz-diorite which occurs at the margins of the pluton and as internal rafts. The other varieties are all coarse (granodiorites) adamellites. The bulk of the pluton is formed by Porphyritic Microcline Type II which occurs as a marginal belt of varying width. Equigranular Type II, which is mineralogically similar but is aphyric, occurs internally within the Northern Pluton. Types III and IV granites are characterized by having muscovite megacrysts and are considered to be either hydrothermally altered varieties of the Type II granites or to represent later magmatic pulses; they occur in the centre of the pluton. The granites show a systematic fractionation sequence from Type I, through Type II, Types III and IV to aplites and pegmatites (Brück \& O'Connor, 1977).

The earliest geochronological work on the Northern Pluton by Kulp et al. (1960) reported a mean K-Ar age of $386 \pm 6 \mathrm{Ma}$ for biotite and muscovite separates of the Porphyritic Microcline Type II granite collected from Dalkey Quarries (Co. Dublin). Lambert \& Mills (1961), working on the same mica separates, obtained a Rb-Sr mineral age of $419 \pm 12 \mathrm{Ma}\left(\lambda^{87} \mathrm{Rb}=1.42 \times 10^{-11} \mathrm{a}^{-1}\right)$. Brown, Miller \& Grasty (1968) subsequently obtained a
K-Ar age of $392 \pm 9 \mathrm{Ma}$ on muscovite separated from the Type III granite of the Northern Pluton at Three Rock Mountain (Co. Dublin). More recently, O'Connor \& Brück (1978) reported a six-point whole-rock $\mathrm{Rb}-\mathrm{Sr}$ errorchron age of $404 \pm 24 \mathrm{Ma}$ for the Northern Pluton based entirely on Type II and aplite samples. An initial ${ }^{87} \mathrm{Sr} /{ }^{88} \mathrm{Sr}$ ratio of $0.708 \pm 0.002$ was obtained for this errorchron.

The aim of the present study was to determine age of emplacement of the granite more precisely from $\mathrm{U}-\mathrm{Pb}$ dating of zircon and monazite separates. Two fresh samples of the Type II granites were collected from the Northern Pluton (Fig. 1): a sample of Porphyritic Microcline Type II granite (862602) from the top of Glenmacnass Waterfall (NGR 3115 2030) and a sample of Equigranular Type II granite (862603) from Ballyknockan Quarry on the eastern shore of Blessington Lake (NGR 3012 2070).

\section{Zircon morphology}

The zircon morphology of the Northern Pluton has already been described in some detail (Gupta 1972, 1973; Gupta \& Elsdon, 1985). In the Type II granites the zircons are mostly euhedral and clear with only a few showing clouding or corrosion. Outgrowths and overgrowths are uncommon and zoning occurs in 10-20\% of the crystals.

Zircons separated from the sample of sparsely Porphyritic Microcline Type II granite (sample 862602, size fraction $-85+70 \mathrm{NM} 3^{\circ}$ ) consist mainly of yellowish, nearly clear, elongate, needle-shaped and pitted crystals. Their length: breadth ratio is predominantly $\geqslant 3$, some crystals show an $1: b$ ratio ranging up to 7 . Some grains show zoning, some have cracks usually connected with dark cores, though rarer zircon-shaped, clear cores can also be seen. Some outgrowths, some rod-shaped inclusions and a few crystals with double terminations can be observed.

The sample of Equigranular Type II granite (862603) yielded very little zircon and therefore all size and magnetic fractions were combined. Morphologically the zircons in this sample are similar to those described above. However, more dark and opaque grains were noted. 


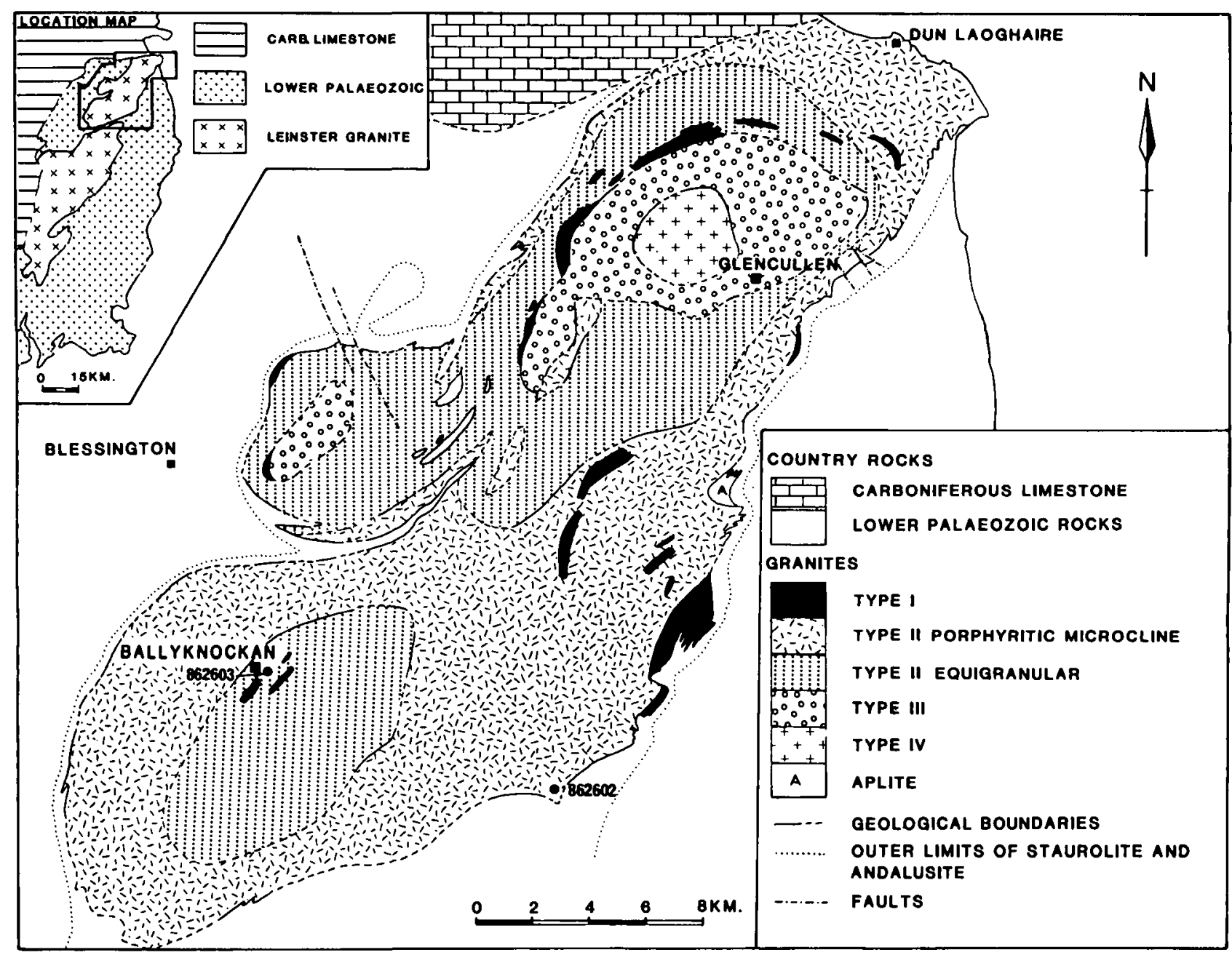

Figure 1. The Northern Pluton of the Leinster granite batholith showing sample locations and disposition of granite types (after Brück, 1974).

\section{Analytical method}

The heavy minerals were separated from the crushed and ground rock samples using a Wilfley table, heavy liquids and a Frantz magnetic separator. The recovered zircons were sieved into different size fractions and again separated according to their magnetic susceptibility. After hand picking to $90 \%$ purity and a wash in dilute acid the zircons were dissolved and $\mathrm{U}$ and $\mathrm{Pb}$ extracted, following closely the method given by Krogh (1973).

After dissolution in concentrated $\mathrm{HCl}$, monazite was similarly treated. The isotopic ratios of $\mathrm{Pb}$ and $\mathrm{U}$ were obtained using a solid source, semi-automatic Micromass 30B mass spectrometer (Vacuum Generators). The isotopic ratios obtained for the NBS radiogenic lead standard SRM 983 are ${ }^{207} \mathrm{~Pb} /{ }^{206} \mathrm{~Pb}=0.071167 \pm 29, \quad{ }^{208} \mathrm{~Pb} /{ }^{206} \mathrm{~Pb}=$ $0.013631 \pm 26$ and ${ }^{206} \mathrm{~Pb} /{ }^{204} \mathrm{~Pb}=2753 \pm 10$, and are within the error limits given.

The isotopic concentrations are corrected for common lead using the composition ${ }^{206} \mathrm{~Pb} /{ }^{204} \mathrm{~Pb}=17.640$, ${ }^{207} \mathrm{~Pb} /{ }^{204} \mathrm{~Pb}=15.582,{ }^{208} \mathrm{~Pb} /{ }^{204} \mathrm{~Pb}=37.665$. This is the composition of the $\mathrm{Pb}$ contained in the nitric acid used, assumed to be the main source of contamination. The two sigma errors for the analytical results are assumed as ${ }^{20} \mathrm{~Pb} /{ }^{206} \mathrm{~Pb}=0.1 \%, \quad{ }^{207} \mathrm{~Pb} /{ }^{235} \mathrm{U}=0.3 \%, \quad{ }^{206} \mathrm{~Pb} /{ }^{238} \mathrm{U}=$ $0.2 \%$. The correlation factor used for the concordia intercept age calculation is 0.8 . The apparent ages are calculated using the decay constants given by Jaffey et al. (1971): $\lambda^{238} U=$ $0.155125 \times 10^{-9} \mathrm{a}^{-1}$ and $\lambda^{235} \mathrm{U}=0.98485 \times 10^{-9} \mathrm{a}^{-1}$. The concordia intercepts were calculated using a modified York regression.

\section{Results and discussion}

The analytical results are presented in Table 1 and in a concordia diagram (Fig. 2). Zircons from both samples of Type II granites are discordant. The data points for the zircons from the sparsely Porphyritic Microcline Type II granite (862602) have retained a small component of inherited radiogenic lead, which is also indicated by the ${ }^{207} \mathrm{~Pb} /{ }^{206} \mathrm{~Pb}$ ages of the coarser size fractions, and group closely near their lower concordia intercept at $393_{-5}^{+2} \mathrm{Ma}$. With a Mean Squared Weighted Deviates (MSWD) value of 6 , their scatter is considerably larger than that attributable to the assumed analytical error. As mentioned above, the data points cluster close to the lower intercept and therefore the upper intercept age is very uncertain and no geological significance can be attached to it.

Sample 862602 also contains monazite which yielded a concordant age of $405 \pm 2 \mathrm{Ma}$ (two sigma error). The closure temperature for the $\mathrm{U}-\mathrm{Pb}$ isotopic system of monazite is considered to be $\geqslant 550^{\circ} \mathrm{C}$ (Cliff, 1985); therefore, the age of the monazite at $405 \pm 2 \mathrm{Ma}$ is probably very close to the age of intrusion of the sparsely Porphyritic 


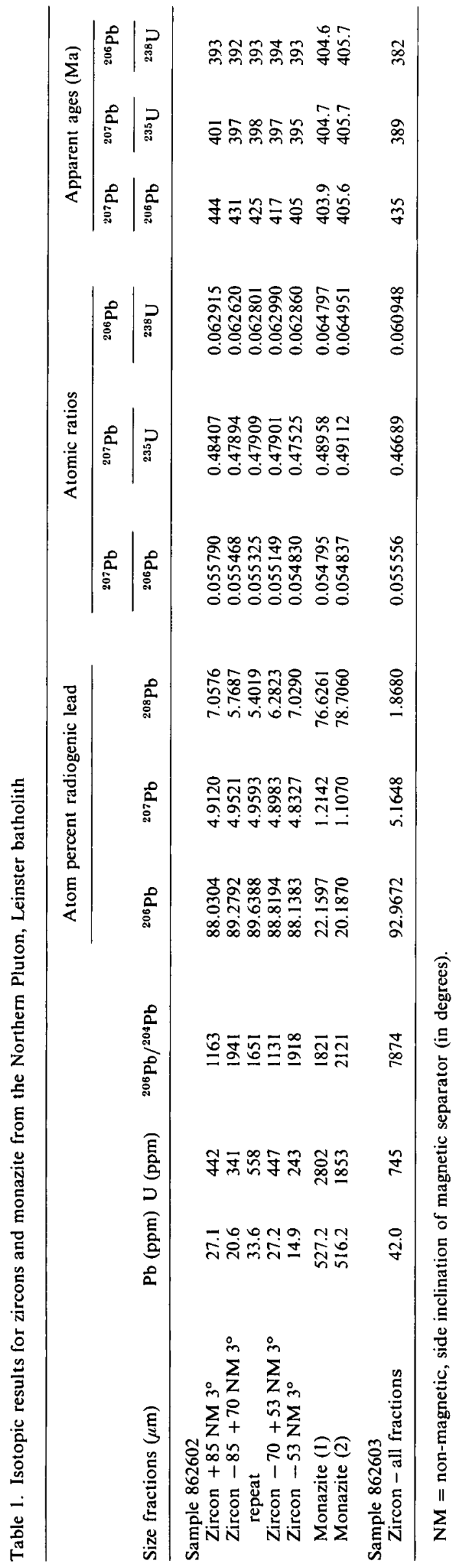

Microcline Type II granite and corresponds to the age of the Siluro-Devonian boundary.

The lower intercept age of the zircons in sample 862602 is then somewhat low due to a rotation of their discordia which was probably caused by some recent $\mathrm{Pb}$ loss. In the coarser size fractions an older inherited radiogenic lead component is indicated by their ${ }^{207} \mathrm{~Pb} /{ }^{200} \mathrm{~Pb}$ ages as mentioned before. However, the finest size fraction $\left(-53 \mathrm{NM} 3^{\circ}\right)$ is situated closest to concordia and has a ${ }^{207} \mathrm{~Pb} /{ }^{206} \mathrm{~Pb}$ age of $405 \pm 2 \mathrm{Ma}$ indicating little or no inherited radiogenic lead. Assuming only a recent lead loss, a chord between the origin of concordia (present day) and the data

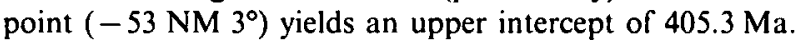
This would suggest that the zircons of the finest size fraction were recrystallized and their U-Pb system was completely reset at the time of the crystallization of the monazite. In other words, they were recrystallized or reset during the intrusion of the granite. The scatter of the data points is larger than the assumed analytical error (see Fig. 2, point $-85+70 \mathrm{NM} 3^{\circ}$ and repeat determination). This indicates a more complex history and probably a mixed origin of this zircon population.

The single data point for the zircons from sample 862603 shows a larger recent lead-loss effect. It does not show any alignment with the data points from sample 862602, apparently indicating no relationship between these two zircon populations. However, more magnetic fractions are usually more affected by lead loss compared to nonmagnetic fractions. Since zircon sample 862603 contains all sizes and all magnetic fractions this conclusion has to be considered with caution.

\section{Conclusions}

The $\mathrm{U}-\mathrm{Pb}$ age data suggest that the age of emplacement of the Northern Pluton of the Leinster Granite batholith is close to $405 \pm 2 \mathrm{Ma}$ derived from monazite separates. This value is in good agreement with the rather imprecise wholerock $\mathrm{Rb}-\mathrm{Sr}$ age reported earlier by O'Connor \& Brück (1978). The age is significant in dating more precisely the main regional deformation event (D1) in southeast Ireland as the Leinster batholith was emplaced synkinematically. The foliation developed in each pluton of the batholith intensifies towards its margins and is concordant with that developed in the aureole schists.

The small component of inherited radiogenic lead in the zircons from the Porphyritic Microcline Type II granite suggests involvement of an old crustal component in the generation of the Leinster Granite. The Rosslare Complex, or sediments derived from it, may represent basement of appropriate age in southeast Ireland which acted as a crustal precursor in the generation of the batholith.

Acknowledgements. The isotope facilities at S.U.R.R.C., East Kilbride are supported by NERC and the Scottish Universities. We thank J. Jocelyn for technical assistance. The paper is published with the permission of the Assistant Director, Geological Survey of Ireland.

\section{References}

Brindley, J. C. 1973. The structural setting of the Leinster Granite, Ireland - a review. Scientific Proceedings of the Royal Dublin Society 5A, 27-36.

Brown, P. E., Miller, J. A. \& Grasty, R. L. 1968. Isotopic 


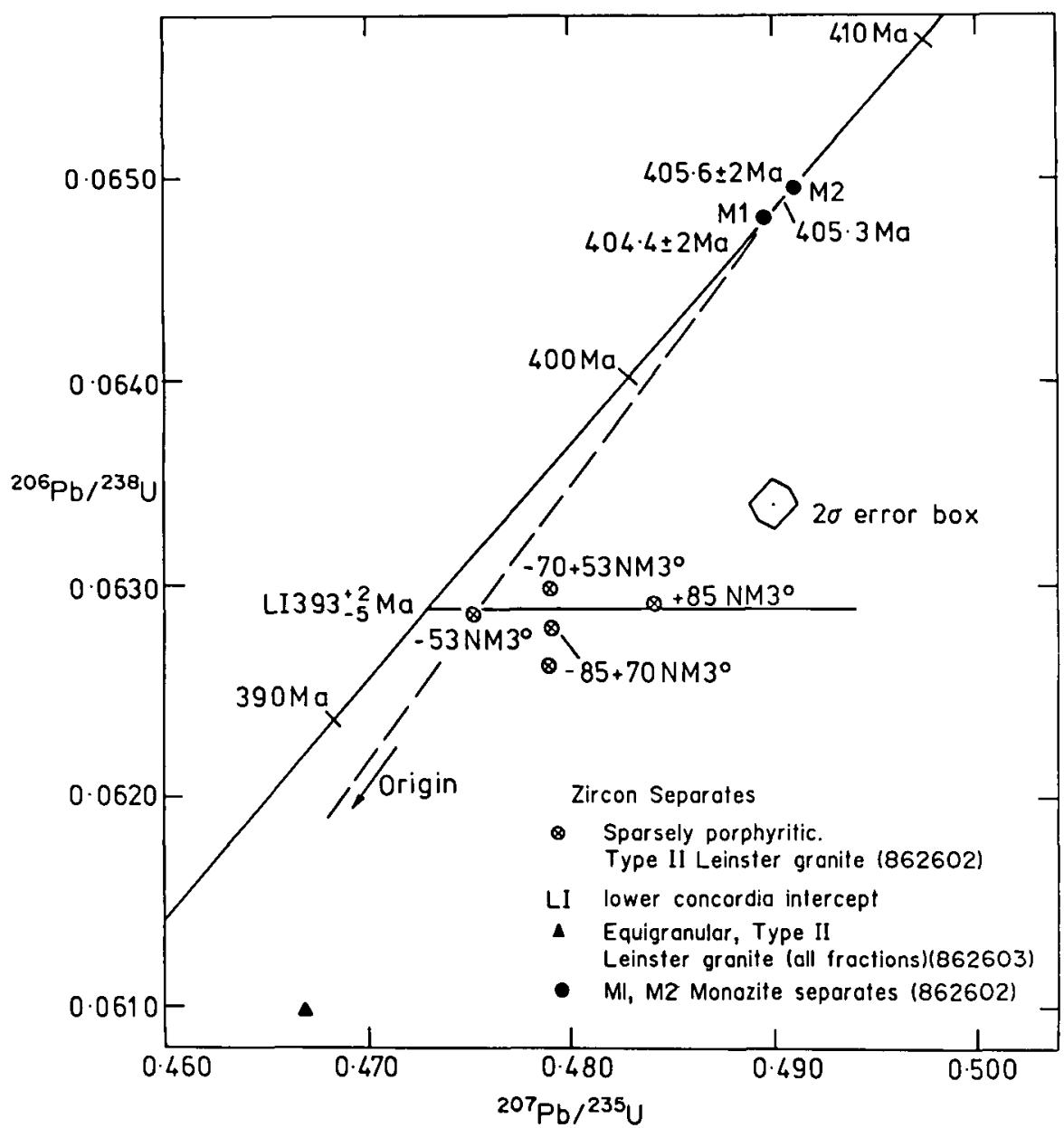

Figure 2. Concordia diagram showing the zircon and monazite data for two samples (862602 and 862603) of Type II granitcs, Leinster batholith. M1, M2 are monazite separates.

ages of later Caledonian granitic intrusions in the British Isles. Proceedings of the Yorkshire Geological Society 36, 251-76.

BRüCK, P. M. 1974. Granite varicties and structures of the Northern and Upper Liffey Valley Units of the Leinster batholith. Bulletin of the Geological Survey of Ireland 1, 381-93.

Brück, P. M. \& O'Connor, P.J. 1977. The Leinster batholith: geology and geochemistry of the Northern Units. Bulletin of the Geological Survey of Ireland 2, 107-41.

CuIfF, R. A. 1985. Isotopic dating in metamorphic belts. Journal of the Geological Society of London 142, 97-110.

Colthurst, J. R. J. \& Smith, D. G. 1977. Palaeontological evidence for the age of the Lower Palaeozoic rocks of the Slievenamon inlier, Co. Tipperary. Proceedings of the Royal Irish Academy 77 B, 145-58.

Gupta, L. N. 1972. Growth trends of zircons from the northern part of the Leinster Granite. Scientific Proceedings of the Royal Dublin Society 4A, 351-70.

Gupta, L. N. 1973. Unusually large zircons from the Leinster pluton. Mineralogical Magazine 39, 253-5.
Gupta, L. N. \& Elsdon, R. 1985. Zircon studics of Unit 1 of the Leinster Granite. Irish Journal of Earth Sciences 7, 65-78.

Jaffey, A. H., Flynn, K. F., Glendenin, L. E., Bentley, W. C. \& Essing, A. M. 1971. Precision measurements of half-lives and specific activities of ${ }^{238} \mathrm{U}$ and ${ }^{235} \mathrm{U}$. Physics Review C4, 1889-1906.

KROGH, T. E. 1973. A low contamination method for hydrothermal decomposition of zircon and extraction of $\mathrm{U}$ and $\mathrm{Pb}$ for isotopic age determinations. Geochimica et Cosmochimica Acta 37, 485-94.

Kulp, J. L., Long, L. E., Griffin, C. E., Mills, A. A., Lambert, R. St. J., Giletti, B. J. \& Webster, R. K. 1960. Potassium-argon and rubidium-strontium ages of some granites from Britain and Eire. Nature 185, 495-7.

Lambert, R. St. J. \& Mills, A. A. 1961. Some critical points for the Palaeozoic time scale from the British Isles. Annals New York Academy of Science 91, 378-8.

O'CONNOR, P. J. \& BRück, P. M. 1978. Age and origin of the Leinster Granite. Journal of Earth Sciences of the Royal Dublin Society 1, 105-13. 